\title{
Herpes Simplex Virus Infection
}

National Cancer Institute

\section{Source}

National Cancer Institute. Herpes Simplex Virus Infection. NCI Thesaurus. Code C155871.

An infection that is caused by herpes simplex virus. 